\title{
Theoretical Study of the Coordination of Semicarbazone and Its Methylated Derivatives
}

\author{
Urbain A. Kuevi $^{1}$, Gaston A. Kpotin ${ }^{1}$, Guy S. Y. Atohoun ${ }^{1}$, Jean-Baptiste Mensah ${ }^{1}$ \\ ${ }^{1}$ Laboratoire de Chimie Théorique et de Spectroscopie Moléculaire (LACTHESMO), Université d'Abomey-Calavi, \\ Bénin \\ Correspondence: Urbain A. Kuevi, Laboratoire de Chimie Théorique et de Spectroscopie Moléculaire (LACTHESMO), \\ Université d'Abomey-Calavi, Bénin. E-mail: urviama@gmail.com
}

Received: November 2, 2017 Accepted: December 7, 2017 Online Published: January 3, 2018

doi:10.5539/ijc.v10n1p1

URL: https://doi.org/10.5539/ijc.v10n1p1

\begin{abstract}
Semicarbazone is a molecule with a group $\mathrm{R}^{1} \mathrm{R}^{2} \mathrm{C}=\mathrm{N}-\mathrm{NR}^{3}-\mathrm{C}(=\mathrm{O})-\mathrm{NR}^{4} \mathrm{R}^{5}$.

The oxygen atom has two free electron pairs; each nitrogen atom has one free electron pair. These free electron pairs are potential sites of coordination. The simplest molecule in this series is the semicarbazone which the formula is $\mathrm{H}_{2} \mathrm{C}=\mathrm{N}-\mathrm{NH}-\mathrm{C}(=\mathrm{O}) \mathrm{NH}_{2}$. By replacing the oxygen atom by a sulfur atom is obtained a thiosemicarbazone. Some semicarbazones, such as nitrofurazone, and some thiosemicarbazones are known to have many properties: antiviral, antibacterial, antitrypanosomal, anticonvulsant, antitumor, anticancer. They are usually mediated by an association with copper or iron.

Indeed transition metal complexes with given chemical structures are useful alternatives in the treatment of certain diseases since coordination of active ingredients deeply modifies both the physiological properties of metals and ligands in the meaning of overall improvement of these properties.
\end{abstract}

The present work focuses on quantum study of the complexation of semicarbazone and its methylated derivatives. The purpose of this study is to determine the most favorable coordination site of each of these ligands. It was found that the oxygen atom appears more favorable to the coordination of semicarbazones.

Complexes of these ligands with the Zn (II) were modeled. The calculations were made by the method DFT / B3LYP with the orbital basis 6-31G (d, p).

Keywords: coordination compounds, semicarbazones, DFT/ B3LYP, 6-31G (d,p) basis set

\section{Introduction}

The study at the molecular level of the interaction between metals and bioligands (proteins, nucleic acids, their fragments, and other substances contained in the organism) is topical (Knouniats, 1990) (Williams, 1975) (Yatsimirskiï, 1976) (Kembal, 1975). The bioinorganic chemistry which is currently in full swing is concerned, inter alias, with the coordination of trace elements with organic ligands. The results of these studies find their applications in various fields of science and technology such as medicine, agriculture, environmental protection, catalysis.

In fact, the coordination of bioligands profoundly modifies both the physiological properties of metals and those of ligands with an overall improvement in the activity of the pure ligand or of the complexing metal salt (Azizov, 1969) (Büchel, Moretto et al. 2000) (Bäuerlein, Arias et al. 2007) (Bäuerlein, Kawasaki et al., 2007) (Bäuerlein, Frankel et al.2007) (Andersen, 1999) (Wong \& Giandomenico, 1999) (Shaw 1999), (Caravan \& Ellison, 1999).

Semicarbazones (SCZ) are molecules having a group $\mathrm{R}^{1} \mathrm{R}^{2} \mathrm{C}=\mathrm{N}-\mathrm{NR} \mathrm{R}^{3} \mathrm{C}(=\mathrm{O})-\mathrm{NR}^{4} \mathrm{R}^{5}$, thus having donor atoms $(\mathrm{N}$ and $\mathrm{O})$ capable of forming bonds with complexing metals. They are of particular interest as ligands. Semicarbazones are derivatives of aldehydes or ketones. They are formed by condensation of these compounds with a semicarbazide as shown by the reaction: $\mathrm{H}_{2} \mathrm{NNHC}(=\mathrm{O}) \mathrm{NH}_{2}+\mathrm{RC}(=\mathrm{O}) \mathrm{R}^{2} \rightarrow \mathrm{RR}^{2} \mathrm{C}=\mathrm{NNHC}(=\mathrm{O}) \mathrm{NH}_{2}+\mathrm{H}_{2} \mathrm{O}$

where $\mathrm{R}^{2}$ is a hydrogen atom (if it is an aldehyde) or an alkyl group (if it is a ketone). The simplest molecule of this series is the semicarbazone of formula $\mathrm{H}_{2} \mathrm{C}=\mathrm{N}-\mathrm{NH}-\mathrm{C}(=\mathrm{O}) \mathrm{NH}_{2}$. Certain semicarbazones, such as nitrofurazone, and certain thiosemicarbazones are known for their antiviral, antibacterial, antitrypanosomal (antiparasitic), anticonvulsive, anti-tumor, anti-cancer, etc. activities, generally mediated by a binding with copper or iron (Picot, 2008) (Sakirigui et al., 2011) (Kenneth, 1999). 
The present work deals with a quantum study of the complexation of semicarbazone and its methylated derivatives. The aim of this study is to determine the most favorable coordination site for each of these ligands and to provide some insights into the complex geometry without which metabolic issues cannot be addressed. The coordination indicators (ICs) used in the studies are: interatomic bond lengths, atomic charges, boundary orbital structures and indexes of electrophilic superdelocalisability.

\section{Materials and Methods}

The present work, which is a theoretical study of the complexation of semicarbazone and its methylated derivatives, was carried out by quantum chemical calculations. These calculations were carried out using the density functional theory (DFT) method with the functional B3LYP. The calculation basis set was 6-31g (d, p). The software used to perform the calculations is the Gaussian 03 and 09 (Frisch et al. 1998). The used computer was a Samsung intel ${ }^{\circledR}$ core i32.4 GHz; the indexes of electrophilic superdelocalisability of the atoms were determined by the D-Cent-QSAR program (Gómez-Jeria, 2014). The different figures were made by the software Gauss view and by Chem Draw ultra 8 . After studying the possibility of complexation of the different ligands with respect to criteria such as geometric parameters, atomic charges, HOMO components and the indexes of électrophilic superdelocalisability (IESD) of the atoms, we have modeled the formation of their respective complexes with zinc chloride (II).

We have tried to elucidate the type of hybridization of Zn (II) and consequently the shape of the complex. The ligands which have been the subject of the present study are semicarbazone and its methylated derivatives. Studies were performed at $25^{\circ} \mathrm{C}$ and $1 \mathrm{~atm}$.

\section{Results and Discussion}

\subsection{Study about the Ligands}

This study allowed predicts the coordinatating sites of ligands by analysis of some system parameters known as coordinating indexes (CI). These IC was the geometric data, the atomic charges, the frontier orbitals, the energetic data, the atomic indexes of superdelolalisability. These data allow to explain the bond formation between donor and acceptor atoms. Figure 1 shows the molecules of the studied in this work semicarbazones (SCZs).

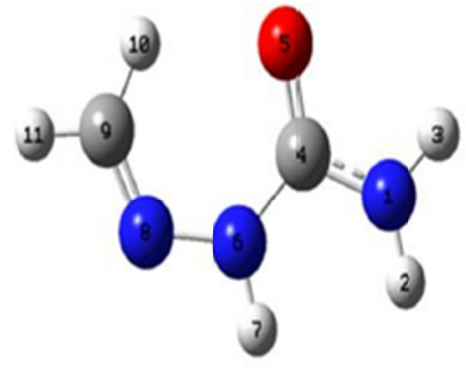

a) Semicarbazone ( $\mathrm{SCZ}$ ), $\Delta \mathrm{G}=-318,62$ hartree or $-8669,87 \mathrm{eV}$

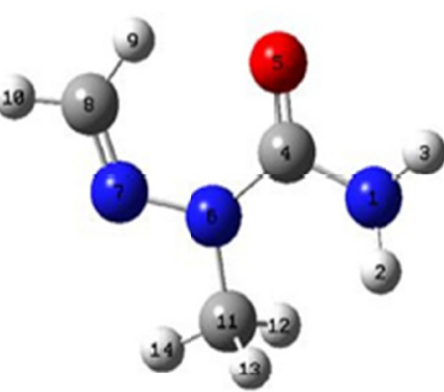

d) 2-methylsemicarbazone (2-MSCZ),

$\Delta \mathrm{G}=-357,91$ hartree or $-9738,98 \mathrm{eV}$

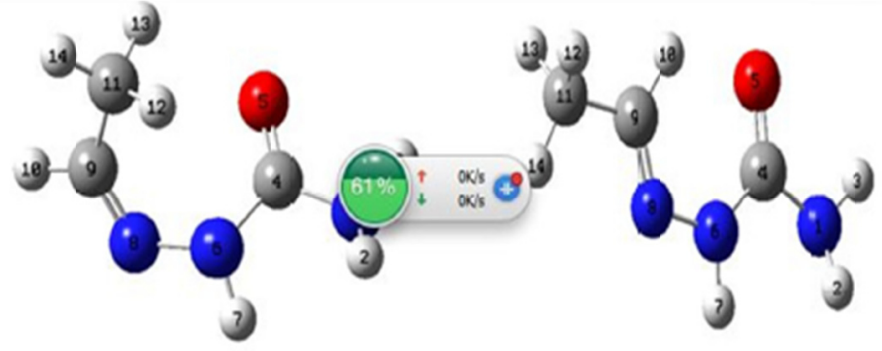

b) Z-Ethanalsemicarbazone (Z-EtSCZ), $\Delta \mathrm{G}=-357,92$ hartree or $-9739,25 \mathrm{eV}$

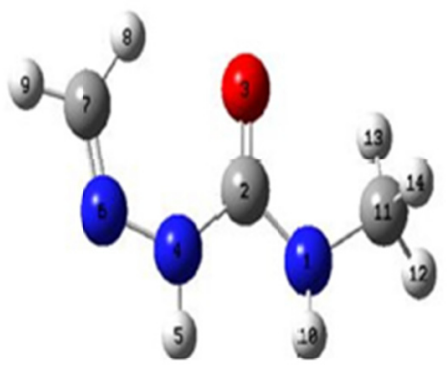

e) 4-methylsemicarbazone

(4-MSCZ),

$\Delta \mathrm{G}=-357,91$ hartree or $-9738,98 \mathrm{eV}$

Figure 1. Calculated, on DFT/B3LYP level, geometries of the studied semicarbazones at $25^{\circ} \mathrm{C}$ and their energies 
It is important to note that the more complete values of $\Delta \mathrm{G}$ are -357.919752 hartree for the Z-Ethanalsemicarbazone and -357.924990 hartree for E-Ethanalsemicarbazone. The value -357.92 hartree which appears under these two isomers is written in the authors' concern to stop at two digits after the decimal point. So there is no question of thinking that the two isomers have the same stability.

\subsubsection{Geometric Analysis}

The table 1 contains some geometric data of the studied ligands. Analysing SCZs molécules we notice that bond lengths $\mathrm{N}^{1} \mathrm{C}^{4}$ and $\mathrm{N}^{6} \mathrm{C}^{4}$ are equal to about $1.39 \AA$. This value is intermediate between $1.47 \AA(\mathrm{C}-\mathrm{N}$ length $)$ and $1.27 \AA(\mathrm{C}=\mathrm{N}$ length) (Mason, 1961) (Potapov \& Tatarintchik, 2008) (Sakurai, Yoshikawa, Yasui, 2008). In other hand we found that $\mathrm{C}^{4} \mathrm{O}^{5}$ bonds are about $1.22 \AA$ long, it correspond to a double $\mathrm{C}=\mathrm{O}$ bond. These observations suggest that the double $\mathrm{C}=\mathrm{O}$ bond interacts with the free $\pi$ electronic pairs of $\mathrm{N}^{1}$ and $\mathrm{N}^{6}$ nitrogen atoms while a part of electronic pairs clouds off $\mathrm{O}$ atom compenses the electronic defect, which issued from this conjugation, at the level of $\mathrm{C}=\mathrm{O}$ double bond. That's why its length has not varied.

Table 1. Geometric parameters of investigated SCZs, *Exp.= experimental values

\begin{tabular}{|c|c|c|c|c|c|c|}
\hline Parameters & $\mathrm{SCZ}$ & Z-EtSCZ & E-EtSCZ & 2-MSCZ & 4-MSCZ & $\begin{array}{l}\text { xp (Mason, 1961) (Potapov \& Tatarintchik, } \\
\text { 008) (Sakurai, Yoshikawa \& Yasui, 2008)* }\end{array}$ \\
\hline \multicolumn{7}{|l|}{ Lengths $(\AA)$} \\
\hline $\mathrm{N}^{1} \mathrm{C}^{4}$ & 1.39 & 1.39 & 1.39 & 1.39 & 1.38 & $\mathrm{C}-\mathrm{N} \rightarrow 1.47 ; \mathrm{C}=\mathrm{N} \rightarrow 1.27$ \\
\hline$C^{4} N^{6}$ & 1.39 & 1.40 & 1.39 & 1.39 & 1.40 & $\mathrm{C}-\mathrm{N} \rightarrow 1.47 ; \mathrm{C}=\mathrm{N} \rightarrow 1.27$ \\
\hline $\mathrm{N}^{6} \mathrm{~N}^{8}$ & 1.37 & 1.41 & 1.38 & 1.38 & 1.37 & $\mathrm{~N}-\mathrm{N} \rightarrow 1.40 ; \mathrm{N}=\mathrm{N} \rightarrow 1.23$ \\
\hline $\mathrm{N}^{8} \mathrm{C}^{9}$ & 1.28 & 1.28 & 1.28 & 1.28 & 1.28 & $\mathrm{C}-\mathrm{N} \rightarrow 1.47 ; \mathrm{C}=\mathrm{N} \rightarrow 1.27$ \\
\hline $\mathrm{C}^{4} \mathrm{O}^{5}$ & 1.22 & 1.22 & 1.22 & 1.22 & 1.22 & $\mathrm{C}-\mathrm{O} \rightarrow 1.43 ; \mathrm{C}=\mathrm{O} \rightarrow 1.21$ \\
\hline $\mathrm{C}^{9} \mathrm{C}^{11}$ & - & 1.50 & 1.50 & - & $1.45 \mathrm{C}^{1} \mathrm{C}^{11}$ & \\
\hline $\mathrm{N}^{6} \mathrm{C}^{11}$ & - & - & - & 1.46 & - & \\
\hline \multicolumn{7}{|l|}{ Angles $\left(^{\circ}\right)$} \\
\hline $\mathrm{N}^{1} \mathrm{C}^{4} \mathrm{O}^{5}$ & 122.78 & 123.21 & 122.52 & 121.35 & 123.3 & \\
\hline $\mathrm{N}^{1} \mathrm{C}^{4} \mathrm{~N}^{6}$ & 112.49 & 112.03 & 112.47 & 114.41 & 112.53 & \\
\hline $\mathrm{O}^{5} \mathrm{C}^{4} \mathrm{~N}^{6}$ & 124.72 & 124.75 & 125.00 & 124.18 & 124.17 & \\
\hline$C^{4} N^{6} N^{8}$ & 129.23 & 120.89 & 128.91 & 125.88 & 129.13 & \\
\hline$N^{6} N^{8} C^{9}$ & 121.15 & 117.04 & 120.77 & 122.97 & 121.33 & \\
\hline $\mathrm{N}^{8} \mathrm{C}^{9} \mathrm{C}^{11}$ & - & 129.92 & 118.30 & - & - & \\
\hline $\mathrm{N}^{4} \mathrm{C}^{6} \mathrm{C}^{11}$ & - & - & - & 121.54 & $\begin{array}{l}119.51 \\
\mathrm{~N}^{4} \mathrm{C}^{1} \mathrm{C}^{11}\end{array}$ & \\
\hline \multicolumn{7}{|l|}{ Dihedrals $\left({ }^{\circ}\right)$} \\
\hline $\mathrm{N}^{1} \mathrm{C}^{4} \mathrm{O}^{5} \mathrm{~N}^{6}$ & 178.14 & 178.69 & 178.51 & 177.13 & 178.93 & \\
\hline$N^{1} C^{4} N^{6} N^{8}$ & -174.70 & -162.11 & -170.99 & 175.19 & -173.96 & \\
\hline $\mathrm{O}^{5} \mathrm{C}^{4} \mathrm{~N}^{6} \mathrm{~N}^{8}$ & 3.60 & 16.71 & 7.64 & -7.52 & 5.07 & \\
\hline$C^{4} N^{6} N^{8} C^{9}$ & -10.77 & -64.71 & -17.11 & 2.99 & -12.00 & \\
\hline$N^{6} N^{8} C^{9} C^{11}$ & - & -3.25 & -179.17 & 1.02 & $\begin{array}{l}-171.92 \\
\mathrm{~N}^{6} \mathrm{C}^{4} \mathrm{~N}^{1} \mathrm{C}^{11}\end{array}$ & \\
\hline
\end{tabular}

The $\mathrm{N}^{6} \mathrm{~N}^{8}$, bond length of which about 1.37, is a single bond while the $\mathrm{N}^{8} \mathrm{C}^{9}$ bond (1.28 $\AA$ ) is a double one (Mason, 1961) (Potapov \& Tatarintchik, 2008) (Sakurai, Yoshikawa \& Yasui, 2008).

The sum of the bond angles arround $\mathrm{C}^{4}$ atom equals $360^{\circ}$ and the dihédral $\mathrm{N}^{1} \mathrm{C}^{4} \mathrm{O}^{5} \mathrm{~N}^{6}$ is about $180^{\circ}$; this means that the three bonds (and the tree atoms) which are arround $\mathrm{C}^{4}$ are in the same plane. Consequently the clouds of the $\pi$ free electronic pairs of $\mathrm{N}^{1}$ et $\mathrm{N}^{6}$ and that of $\pi \mathrm{C}=\mathrm{O}$ have a same orientation, so it is a confirmation that they forms conjugation bonds $\mathrm{N}^{1} \mathrm{C}^{4}, \mathrm{~N}^{6} \mathrm{C}^{4}$ and $\mathrm{C}^{4} \mathrm{O}$. This electronic pairs delocalization is not favorable to a coordination trough the $\mathrm{N}^{1}$ and $\mathrm{N}^{6}$ nitrogen atoms. Thus we can tell that the bond lengths as $\mathrm{CI}$ are not favorable to coordination with a metal ion trough the $\mathrm{N}^{1}$ and $\mathrm{N}^{6}$; contrarly that indice is favorable to coordination trough $\mathrm{O}$ and $\mathrm{N}^{8}$ because their free electronic pairs are quasi no delocalized (Douglas \& Anthony, 1993).

\subsubsection{Atomic Charges Analysis}

The table 2 corresponds to the atomic charges of the investigated ligands. In these ligands one notice that the atomic charges of $\mathrm{N}^{1}, \mathrm{~N}^{6}$ et $\mathrm{O}^{5}$ are about $-0,7$ a.u.; the $\mathrm{N}^{8}$ atoms carry rather positive charges $(0.086 ; 0.035 ; 0.077$ et 0.105 a.u. respectivly for SCZ, Z-EtSCZ, E-EtSCZ, 2-MSCZ and 4-MSCZ). Thus the charge as CI is not favorable to a coordination though $\mathrm{N}^{8}$. Although the $\mathrm{N}^{1}$ and $\mathrm{N}^{6}$ atoms are negatively charged, the coordination through them is disadvantaged by their rather positive environment; in fact $\mathrm{H}^{2}, \mathrm{H}^{3}, \mathrm{H}^{7}$ et $\mathrm{C}^{11}$ carry high positive charges (about 0.2 a.u. for hydrogen atoms and 0.3 a.u. for $\mathrm{C}^{11}$ ) capable of repelling the coordination cation. These reasons assume that the charge is favorable for the coordination of the semicarbazones via the oxygen atom. 
Table 2. Atomic charges (a.u.)

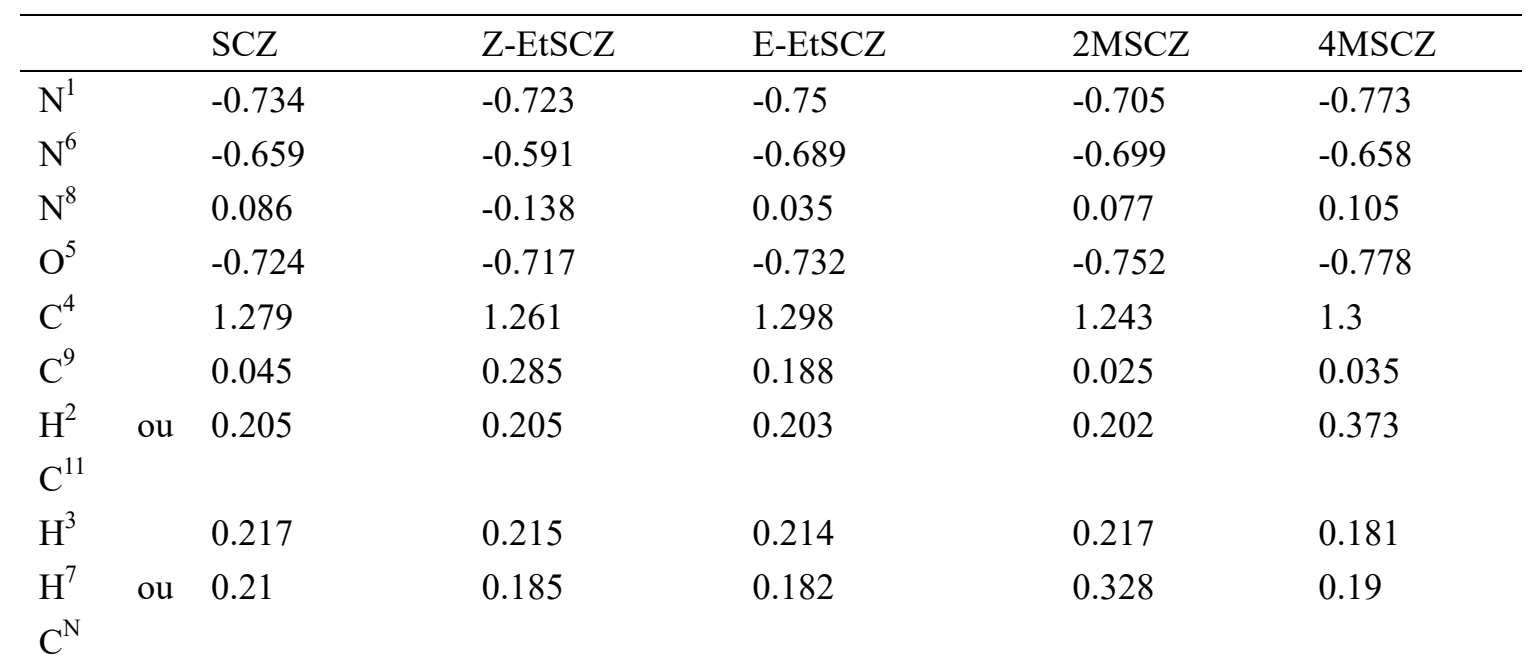

\subsubsection{Frontier Orbitals Analysis}

The table 3 shows some energetic values of studied SCZs. One notice that the HOMO et HOMO-1 are respectively of $-6,5 \mathrm{eV}$ et $-7 \mathrm{eV}$; these molecular orbitals are dominated respectively by the $\mathrm{p}_{\mathrm{z}}$ atomic orbital of $\mathrm{N}^{6}$ and the $\mathrm{p}_{\mathrm{x}}$ atomic orbital of $\mathrm{O}$. According to this analysis, the frontier orbitals indicate that the coordinating favorable sites of studied SCZs in this investigation work are $\mathrm{N}^{6}$ nitrogen atom and $\mathrm{O}$.

Table 3. Energetic values of the investigated SCZs

\begin{tabular}{|c|c|c|c|c|c|c|}
\hline \multirow[t]{2}{*}{ Orbitals } & \multicolumn{2}{|c|}{ SCZ } & \multicolumn{2}{|c|}{ Z-EtSCZ } & \multicolumn{2}{|c|}{ E-EtSCZ } \\
\hline & $\begin{array}{l}\text { Energies } \\
(\mathrm{eV})\end{array}$ & $\begin{array}{c}\text { dominant atomic } \\
\text { orbitals }\end{array}$ & $\begin{array}{l}\text { Energies } \\
(\mathrm{eV})\end{array}$ & $\begin{array}{c}\text { dominant atomic } \\
\text { orbitals }\end{array}$ & $\begin{array}{l}\text { Energies } \\
\quad(\mathrm{eV})\end{array}$ & $\begin{array}{c}\text { dominant atomic } \\
\text { orbitals }\end{array}$ \\
\hline HOMO-1 & $-6,85$ & $\begin{array}{c}\mathrm{O} \\
\mathrm{px}(0.72)\end{array}$ & $-7,08$ & $\mathrm{O} p \mathrm{px}(0,74)$ & $-6,73$ & $\begin{array}{c}\mathrm{O} \\
\mathrm{px}(0,72)\end{array}$ \\
\hline HOMO & $-6,66$ & $\mathrm{~N}^{6} \mathrm{pz}(0.78)$ & $-6,29$ & $\mathrm{~N}^{6} \mathrm{pz}(0,74)$ & $-6,35$ & $\begin{array}{c}\mathrm{N}^{6} \\
\operatorname{pz}(0.76)\end{array}$ \\
\hline $\begin{array}{c}\text { Sites } \\
\text { favorables }\end{array}$ & \multicolumn{2}{|c|}{$\mathrm{O}$ and $\mathrm{N}^{6}$} & \multicolumn{2}{|c|}{$\mathrm{O}$ and $\mathrm{N}^{6}$} & \multicolumn{2}{|c|}{$\mathrm{O}$ and $\mathrm{N}^{6}$} \\
\hline \multirow[t]{2}{*}{ Orbitals } & \multicolumn{2}{|c|}{ 2MSCZ, } & \multicolumn{2}{|c|}{ 4MSCZ } & \multicolumn{2}{|c|}{$\mathrm{ZnCl}_{2}$, } \\
\hline & $\begin{array}{l}\text { Energies } \\
(\mathrm{eV})\end{array}$ & $\begin{array}{c}\text { dominant atomic } \\
\text { orbitals }\end{array}$ & $\begin{array}{c}\text { Energies } \\
(\mathrm{eV})\end{array}$ & $\begin{array}{c}\text { dominant atomic } \\
\text { orbitals }\end{array}$ & $\begin{array}{l}\text { Energies } \\
(\mathrm{eV})\end{array}$ & $\begin{array}{c}\text { dominant atomic } \\
\text { orbitals }\end{array}$ \\
\hline HOMO-1 & $-6,72$ & $\mathrm{Op}(0,71)$ & $-6,69$ & $\mathrm{O} p \mathrm{px}(0,67)$ & - & - \\
\hline HOMO & $-6,35$ & $\mathrm{~N}^{6} \mathrm{pz}(0.82)$ & $-6,52$ & $\mathrm{~N}^{6} \mathrm{pz}(0.77)$ & - & - \\
\hline LUMO & - & - & - & - & $-2,18$ & $\mathrm{Zn} \mathrm{s}(2,01)$ \\
\hline $\begin{array}{l}\text { LUMO+1 } \\
\text { Sites } \\
\text { favorables }\end{array}$ & \multicolumn{2}{|c|}{$\mathrm{O}$ and $\mathrm{N}^{6}$} & \multicolumn{2}{|c|}{$\mathrm{O}$ and $\mathrm{N}^{6}$} & \multicolumn{2}{|r|}{ - } \\
\hline
\end{tabular}

3.1.4 Atomic Indexes of Electropphilic Superdelocalisability (IESD) Analysis

The main IESDs are shown in the table 4 . We can notice that all these indexes are negatives.

Table 4. IESD values of studied SCZs atoms

\begin{tabular}{llllll}
\hline \multirow{2}{*}{ Atoms } & \multicolumn{5}{c}{ IESD, eV } \\
\cline { 2 - 6 } & SCZ & Z-EtSCZ & E-EtSCZ & 2MSCZ & 4MSCZ \\
\hline $\mathrm{N}^{1}$ & -0.449 & -0.453 & -0.454 & -0.452 & -0.450 \\
$\mathrm{~N}^{6}$ & -0.418 & -0.436 & -0.426 & -0.418 & -0.424 \\
$\mathrm{~N}^{8}$ & -0.459 & -0.479 & -0.476 & -0.464 & -0.463 \\
$\mathrm{O}^{5}$ & -0.603 & -0.611 & -0.611 & -0.616 & -0.612 \\
$\mathrm{C}^{4}$ & -0.234 & -0.241 & -0.237 & -0.237 & $-0 . .234$ \\
$\mathrm{C}^{9}$ & -0.354 & -0.326 & -0.338 & -0.359 & -0.358 \\
$\mathrm{H}^{2}$ & 0.049 & -0.050 & -0.050 & -0.049 & - \\
$\mathrm{H}^{3}$ & -0.048 & -0.049 & -0.049 & -0.049 & -0.234 \\
$\mathrm{H}^{7}$ & -0.048 & -0.050 & -0.049 & - & -0.049 \\
\hline
\end{tabular}


The atomic index of electrophilic superdelocalizability is an magnitude which shows the capacity of given specie to attract a electrophile system. The coordination is thought to be more likely at the level of the atom with the most negative IESD (Gómez-Jeria, 2014). Thus the table 5 revels that oxygen atom. $(-0,6 \mathrm{eV})$ is the more favorable coordination site for all studied ligands. It is followed by the trigonal nitrogen atom $\mathrm{N}^{8}$ (about $0,46 \mathrm{eV}$ ).

\subsubsection{Recapitulative Analysis}

In the table 5 you can read, at the intersection of each ligand with each CI, the atom through which coordination can occur during a complexation process.

Table 5. Recapitulative analysis, ${ }^{*} \mathrm{BL}=$ Bond lengths, $* * \mathrm{AC}=$ Atomic charges

\begin{tabular}{llllll}
\hline $\begin{array}{c}\text { molecules } \\
\text { CI }\end{array}$ & SCZ & E-EtSCZ & E-EtSCZ & 2MSCZ & $4 \mathrm{MSCZ}$ \\
\hline $\mathrm{BL}^{*}$ & $\mathrm{O}, \mathrm{N}^{8}$ & $\mathrm{O}, \mathrm{N}^{8}$ & $\mathrm{O}, \mathrm{N}^{8}$ & $\mathrm{O}, \mathrm{N}^{8}$ & $\mathrm{O}, \mathrm{N}^{8}$ \\
$\mathrm{AC}^{* *}$ & $\mathrm{O}$ & $\mathrm{O}$ & $\mathrm{O}$ & $\mathrm{O}$ & $\mathrm{O}$ \\
$\mathrm{HOMO}$ & $\mathrm{O}, \mathrm{N}^{6}$ & $\mathrm{O}, \mathrm{N}^{6}$ & $\mathrm{O}, \mathrm{N}^{6}$ & $\mathrm{O}, \mathrm{N}^{6}$ & $\mathrm{O}, \mathrm{N}^{6}$ \\
$\mathrm{ISDE}$ & $\mathrm{O}$ & $\mathrm{O}$ & $\mathrm{O}$ & $\mathrm{O}$ & $\mathrm{O}$ \\
\hline
\end{tabular}

It can be seen that all the CIs considered are favorable for the coordination of the studied semicarbazones via the oxygen atom. Coordination through $\mathrm{N}^{8}$ or $\mathrm{N}^{6}$ is less likely. No CI is favorable for coordination of semicarbazones, object of the present study, by $\mathrm{N}^{1}$.

These results should be confirmed by modeling the complexes of these molecules.

The choice in the present study is focused on zinc (II), a trace element that is very present in the treatment of various pathologies. Its electronic structure is $1 s 22 s^{2} 2 p^{6} 3 s^{2} 3 p^{6} 4 s^{0} 3 d^{10} 4 p^{0}$. Zinc (II) generally gives tetrahedral complexes close to the Td point group. This is understandable when one observes its electronic structure: the orbital $s, p_{x}, p_{y}$ and $p_{z}$ are vacant and are capable of $\mathrm{sp}^{3}$ hybridization. The $\mathrm{sp}^{3}$ hybrid orbitals point to the tops of a tetrahedron. The orbital $\mathrm{p}$ of atoms recognized as favorable for the coordination of the ligands studied are capable to overlap with these $\mathrm{sp}^{3}$ orbitals.

\subsection{Modeling of Coordination Compounds}

\subsubsection{Modeling}

Semicarbazone complexes $\mathrm{ZnCl}_{2}$.Ligand were modeled. They are $\mathrm{ZnCl}_{2} \cdot \mathrm{SCZ}, \mathrm{ZnCl}_{2} \cdot \mathrm{Z}$-EtSCZ, $\mathrm{ZnCl}_{2} \cdot \mathrm{E}-\mathrm{EtSCZ}$, $\mathrm{ZnCl}_{2} .2 \mathrm{MSCZ}$ and $\mathrm{ZnCl}_{2} .4 \mathrm{MSCZ}$. Their structures and geometic parameters are shown respectively in the figure $2 \mathrm{a}$ and the table $7 \mathrm{a}$. They are some chelates having tetrahedral stucture. The coordination with the complexing atom took place via the oxygen atom (the length of $\mathrm{Zn}-\mathrm{O}$ equals about $2 \AA$ ) and the trigonal nitrogen atom of the ligand (length of Zn-N8 equals about $2 \AA$ ) forming a pentagonal ring, which is known to be more stable than if the coordination was established by $\mathrm{N}^{6}$ instead of $\mathrm{N}^{8}$ since the cycle tension would be, in this case, higher. These results are consistent with the literature data (Douglas, West \& Anthony, 1993) (Alomar., 2012).

Semicarbazone complexes $\mathrm{ZnCl}_{2}$.2Ligand $\left(\mathrm{ZnCl}_{2} .2 \mathrm{SCZ}, \mathrm{ZnCl}_{2}\right.$.2 (Z-EtSCZ), $\mathrm{ZnCl}_{2}$.2(E-EtSCZ), $\mathrm{ZnCl}_{2} \cdot 2(2 \mathrm{MSCZ})$ et $\mathrm{ZnCl}_{2}$.2(4MSCZ)) were modeled too. These complexes have tetrahedral structure too. Their structures are shown in figure $2 \mathrm{~b}$ and, in the table $6 \mathrm{~b}$, are recorded some of their geometric data. It is found that the interatomic distances $\mathrm{ZnO}$ are of the order $2 \AA$, length of the $\mathrm{Zn}-\mathrm{O}$ bond according to the data of the literature (Kuevi, 1992); there is no ZnN link. It can be deduced that the molecules of the semicarbazones that are the subject of the present works, in the proportion $\mathrm{Zn} /$ ligand $=1 / 2$, have entered into coordination via the oxygen atom.

From all the foregoing it emerges that the combination of the analysis of interatomic distances, atomic charges, electrostatic potentials, atomic indices of superdelocalizabilty and the frontier orbitals of the ligands constitute a fairly effective means of studying the coordination of semicarbazones. An energetic study of the complexation processes made it possible to assess the stability of the coordination compounds of these ligands with $\mathrm{Zn}$ (II). 
Table 6a. Some geometric data of the modelised complexes $\mathrm{ZnCl}_{2}$.Ligand

\begin{tabular}{|c|c|c|c|c|c|}
\hline & $\mathrm{ZnCl}_{2} \cdot \mathrm{SCZ}$ & $\mathrm{ZnCl}_{2}$.E-EtSCZ & $\mathrm{ZnCl}_{2} \cdot \mathrm{Z}-\mathrm{EtSCZ}$ & $\mathrm{ZnCl}_{2} .2 \mathrm{MSCZ}$ & $\mathrm{ZnCl}_{2} .4 \mathrm{MSCZ}$ \\
\hline \multicolumn{6}{|c|}{ Distances $(\AA)$} \\
\hline $\mathrm{Zn}-\mathrm{O}^{5}$ & 2.09 & 2,09 & 2,09 & 2,07 & 2,08 \\
\hline $\mathrm{Zn}-\mathrm{N}^{1}$ & 4,17 & 4,17 & 4,17 & 4,15 & 4,16 \\
\hline $\mathrm{Zn}-\mathrm{N}^{6}$ & 2,94 & 2,93 & 2,94 & 2,97 & 2,94 \\
\hline $\mathrm{Zn}-\mathrm{N}^{8}$ & 2,19 & 2,17 & 2,17 & 2,17 & 2,19 \\
\hline $\mathrm{Zn}-\mathrm{Cl}^{13}$ & 2,19 & 2,19 & 2,19 & 2,19 & 2,19 \\
\hline $\mathrm{Zn}-\mathrm{Cl}^{14}$ & 2,19 & 2,19 & 2,19 & 2,19 & 2,19 \\
\hline \multicolumn{6}{|c|}{ Dihedrals $\left({ }^{\circ}\right)$} \\
\hline $\mathrm{O}^{5} \mathrm{C}^{4} \mathrm{~N}^{6} \mathrm{~N}^{8}$ & $-0,57$ & $-2,77$ & $-2,74$ & 8,34 & $-2,79$ \\
\hline $\mathrm{N}^{1} \mathrm{C}^{4} \mathrm{~N}^{6} \mathrm{~N}^{8}$ & 178,23 & 176,42 & 176,44 & $-177,65$ & 176,79 \\
\hline$C^{4} N^{6} N^{8} C^{9}$ & $-175,08$ & $-174,72$ & $-174,75$ & $-179,33$ & $-176,23$ \\
\hline $\mathrm{N}^{6} \mathrm{~N}^{8} \mathrm{C}^{9} \mathrm{C}^{11}$ & - & 0,12 & 0,12 & 3,07 & - \\
\hline $\mathrm{ZnOC}^{4} \mathrm{~N}^{1}$ & 177,54 & $-179,35$ & $-179,37$ & 169,91 & $-176,99$ \\
\hline $\mathrm{ZnOC}^{4} \mathrm{~N}^{6}$ & $-3,73$ & $-0,22$ & $-0,24$ & $-12,17$ & 2,55 \\
\hline
\end{tabular}

Table $6 \mathrm{~b}$. Some geometric data of the modelised complexes $\mathrm{ZnCl}_{2}$.2Ligand

\begin{tabular}{|c|c|c|c|c|c|}
\hline & $\mathrm{ZnCl}_{2} \cdot 2 \mathrm{SCZ}$ & $\mathrm{ZnCl}_{2} .2 \mathrm{E}-\mathrm{EtSCZ}$ & $\mathrm{ZnCl}_{2} \cdot 2 \mathrm{Z}-\mathrm{EtSCZ}$ & $\mathrm{ZnCl}_{2} .2(2 \mathrm{MSCZ})$ & $\mathrm{ZnCl}_{2} \cdot 2$ (4MSCZ) \\
\hline \multicolumn{6}{|l|}{ Distances $(\AA)$} \\
\hline $\mathrm{Zn}-\mathrm{O}^{5}$ & 2.00 & 1.99 & 1.99 & 2.00 & 2.00 \\
\hline $\mathrm{Zn}-\mathrm{O}^{19}$ & 2.00 & 1.99 & 1.99 & 2.00 & 2.00 \\
\hline $\mathrm{Zn}-\mathrm{N}^{1}$ & 3.40 & 3.40 & 3.42 & 3.40 & 3.36 \\
\hline $\mathrm{Zn}-\mathrm{N}^{15}$ & 3.40 & 3.40 & 3.42 & 3.40 & 3.36 \\
\hline $\mathrm{Zn}-\mathrm{N}^{6}$ & 4.21 & 4.14 & 4.22 & 4.21 & 4.22 \\
\hline $\mathrm{Zn}-\mathrm{N}^{20}$ & 4.21 & 4.14 & 4.22 & 4.21 & 4.22 \\
\hline $\mathrm{Zn}-\mathrm{N}^{8}$ & 4.84 & 4.71 & 4.72 & 4.84 & 4.86 \\
\hline $\mathrm{Zn}-\mathrm{N}^{22}$ & 4.84 & 4.71 & 4.72 & 4.84 & 4.86 \\
\hline $\mathrm{Zn}-\mathrm{Cl}^{13}$ & 2.20 & 2.22 & 2.21 & 2.20 & 2.20 \\
\hline $\mathrm{Zn}-\mathrm{Cl}^{14}$ & 2.31 & 2.30 & 2.31 & 2.31 & 2.33 \\
\hline \multicolumn{6}{|l|}{ Diedrals $\left({ }^{\circ}\right)$} \\
\hline $\mathrm{O}^{5} \mathrm{C}^{4} \mathrm{~N}^{6} \mathrm{~N}^{8}$ & 0.51 & 9.24 & 16.5 & 0.51 & -0.13 \\
\hline $\mathrm{N}^{1} \mathrm{C}^{4} \mathrm{~N}^{6} \mathrm{~N}^{8}$ & -177.32 & -169.08 & -162.74 & -177.32 & -179.31 \\
\hline $\mathrm{C}^{4} \mathrm{~N}^{6} \mathrm{~N}^{8} \mathrm{C}^{9}$ & -19.61 & -45.39 & -70.01 & -19.61 & -14.82 \\
\hline $\mathrm{N}^{6} \mathrm{~N}^{8} \mathrm{C}^{9} \mathrm{C}^{11}$ & - & 179.82 & -2.8 & -5.76 & -4.27 \\
\hline $\mathrm{ZnOC}^{4} \mathrm{~N}^{1}$ & -25.36 & -38.20 & -20.57 & -25.36 & -19.56 \\
\hline $\mathrm{ZnOC}^{4} \mathrm{~N}^{6}$ & 156.97 & 143.59 & 160.24 & 156.97 & 161.31 \\
\hline
\end{tabular}




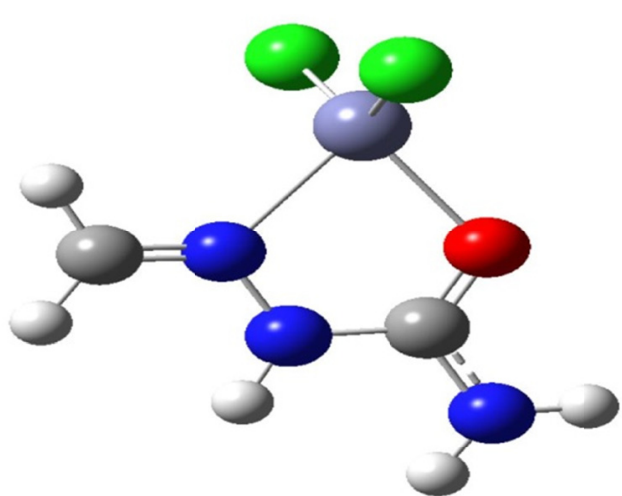

a) $\mathrm{ZnCl}_{2} \cdot \mathrm{SCZ}$

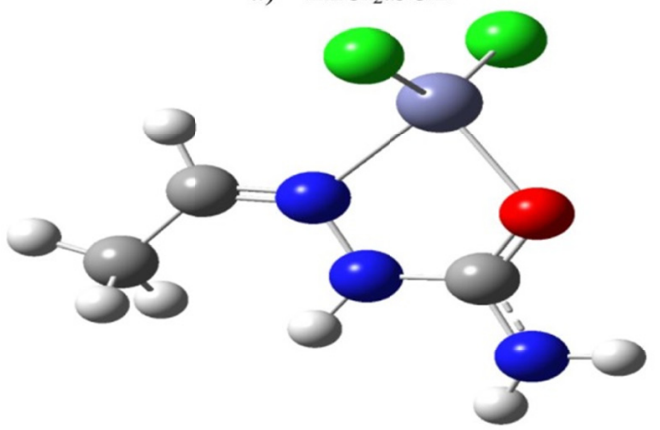

c) $\mathrm{ZnCl}_{2} \cdot \mathrm{Z}$-EtSCZ

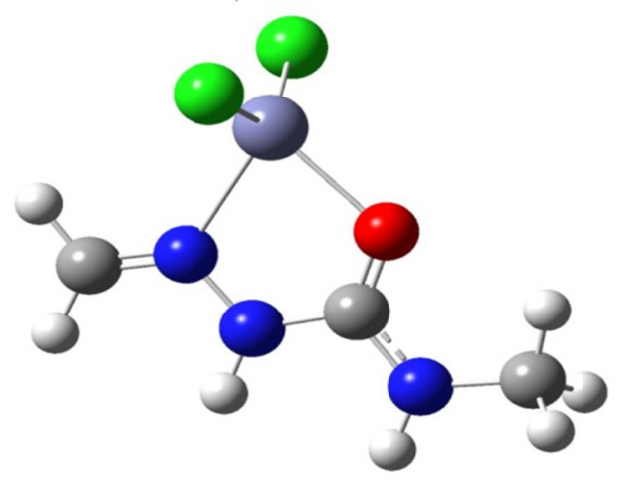

e) $\mathrm{ZnCl}_{2} \cdot 4 \mathrm{ZmétSCZ}$

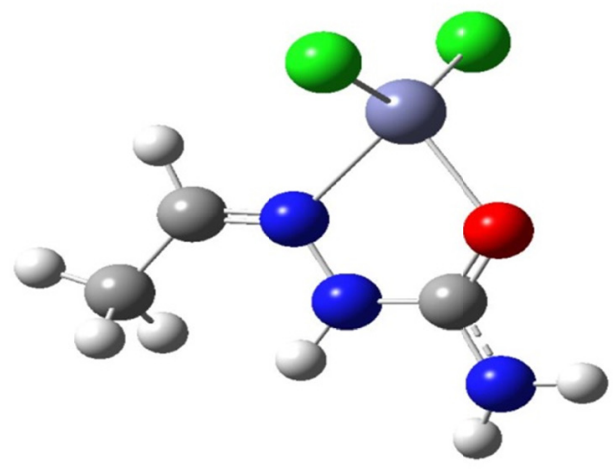

b) $\mathrm{ZnCl}_{2} \cdot \mathrm{E}-\mathrm{EtSCZ}$

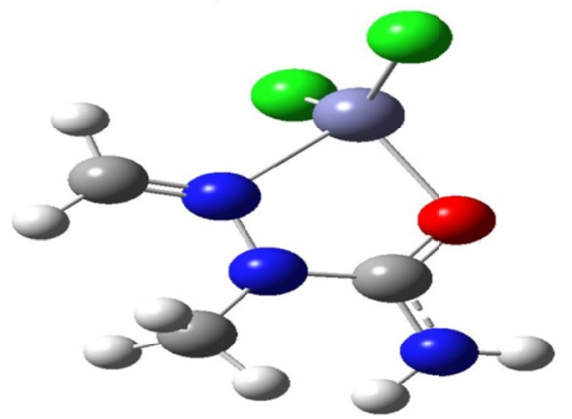

d) $\mathrm{ZnCl}_{2} \cdot 2-\mathrm{MSCZ}$

Figure 2a. Structures of the modelised complexes $\mathrm{ZnCl}_{2}$.Ligand 


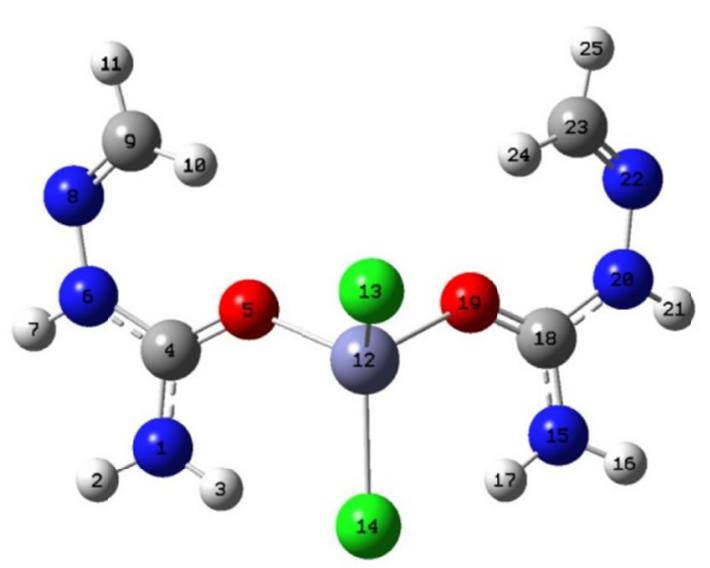

$\mathrm{ZnCl}_{2}(\mathrm{SCZ})_{2}$

Dichlorodisemicarbazonezinc(II)

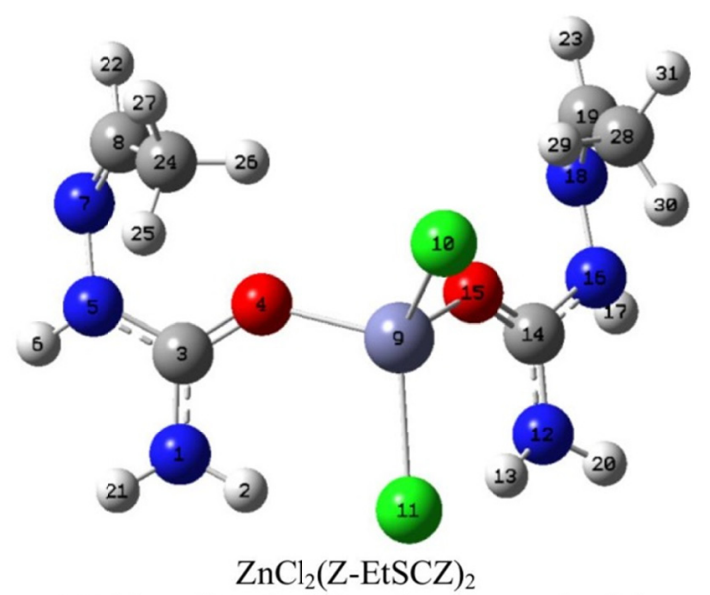

DichlorodiZ-ethanalsemicarbazonezinc(II)

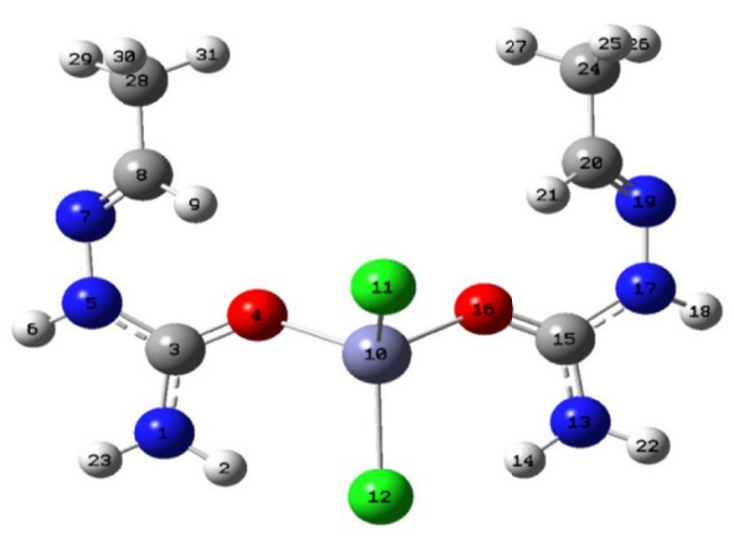

$\mathrm{ZnCl}_{2}(\mathrm{E}-\mathrm{EtSCZ})_{2}$

DichlorodiE-ethanalsemicarbazonezinc(II)

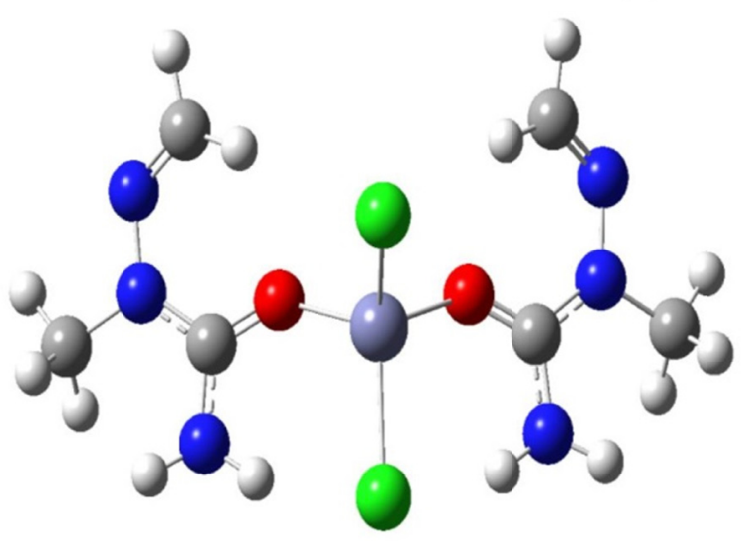

$\mathrm{ZnCl}_{2}(2 \mathrm{MSCZ})_{2}$

Dichlorodi2-methylsemicarbazonezinc(II)

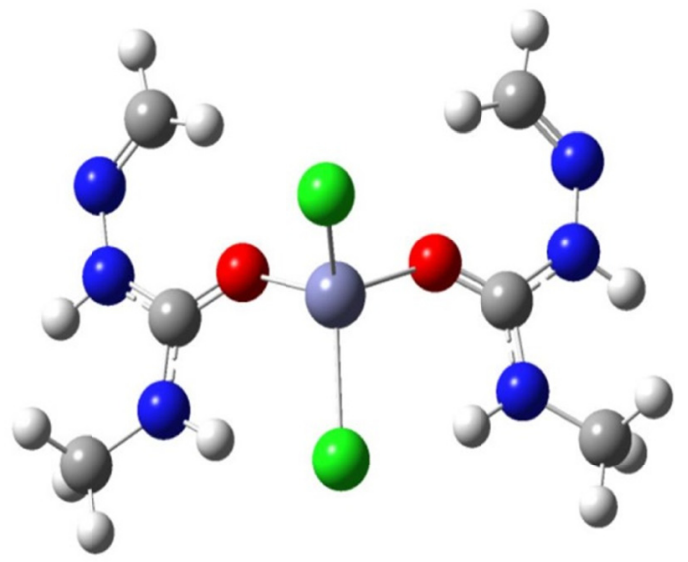

$\mathrm{ZnCl}_{2}(4 \mathrm{MSCZ})_{2}$

Dichlorodi4-methylsemicarbazonezinc(II)

Figure $2 \mathrm{~b}$. Structures of the modelised complexes $\mathrm{ZnCl}_{2}$.2Ligand 


\subsubsection{Energy Study}

The study of the energy of coordination between ligands and zinc (II) chloride was used to assess the stability of the coordination bond. Le table 8 present shows energy values.

$\Delta \mathrm{G}=$ Free enthalpy of the species

$\Delta \mathrm{G}_{\text {coord }}=$ Free enthalpy of coordination

$\Delta \mathrm{G}_{\text {coord }}=\Delta \mathrm{G}_{\text {complexe }}-\left(\Delta \mathrm{G}_{\text {ligand }}+\Delta \mathrm{G}_{\mathrm{ZnCl} 2}\right)$ ou $\Delta \mathrm{G}_{\text {coord }}=\Delta \mathrm{G}_{\text {complexe }}-\left(2 \Delta \mathrm{G}_{\text {ligand }}+\Delta \mathrm{G}_{\mathrm{ZnCl} 2}\right)$

$\Delta \mathrm{H}=$ Enthalpy of the species

$\Delta \mathrm{H}_{\text {coord }}=$ Enthalpy of coordination

$\Delta \mathrm{H}_{\text {coord }}=\Delta \mathrm{H}_{\text {complexe }}-\left(\Delta \mathrm{H}_{\text {ligand }}+\Delta \mathrm{H}_{\mathrm{ZnCl} 2}\right)$ ou $\Delta \mathrm{H}_{\text {coord }}=\Delta \mathrm{H}_{\text {complexe }}-\left(2 \Delta \mathrm{H}_{\text {ligand }}+\Delta \mathrm{H}_{\mathrm{ZnC1} 2}\right)$

Table 7. Some energies of the studied systems

\begin{tabular}{|c|c|c|c|c|c|}
\hline & $\Delta \mathrm{H}, \mathrm{eV}$ & $\Delta \mathrm{H}_{\text {coord, }}, \mathrm{eV}$ & $\Delta \mathrm{G}, \mathrm{eV}$ & $\Delta \mathrm{G}_{\text {coord, }}, \mathrm{eV}$ & Type de processus \\
\hline $\mathrm{ZnCl}_{2}$ & $-73458,28$ & - & $-73459,09$ & - & - \\
\hline $\mathrm{SCZ}$ & $-8669,06$ & - & $-8669,87$ & - & - \\
\hline E-EtSCZ & $-9738,17$ & - & $-9739,25$ & - & - \\
\hline Z-EtSCZ & $-9738,17$ & - & $-9739,25$ & - & - \\
\hline 2MSCZ & $-9737,89$ & - & $-9738,98$ & - & - \\
\hline 4MSCZ & $-9737,89$ & - & $-9738,98$ & - & - \\
\hline \multicolumn{6}{|c|}{ Complexes $\mathrm{ZnCl}_{2}$.Ligand } \\
\hline $\mathrm{ZnCl}_{2} \cdot \mathrm{SCZ}$ & $-82128,70$ & $-1,35$ & $-82130,33$ & $-1,37$ & Exothermic and Spontaneous \\
\hline $\mathrm{ZnCl}_{2} \cdot \mathrm{E}-\mathrm{EtSCZ}$ & $-83197,80$ & $-1,35$ & $-83199,71$ & $-1,37$ & Exothermic and Spontaneous \\
\hline $\mathrm{ZnCl}_{2} \cdot \mathrm{Z}-\mathrm{EtSCZ}$ & $-83198,07$ & $-1,62$ & $-83199,71$ & $-1,37$ & Exothermic and Spontaneous \\
\hline $\mathrm{ZnCl}_{2} \cdot 2 \mathrm{MSCZ}$ & $-83197,53$ & $-1,36$ & $-83199,16$ & $-1,09$ & Exothermic and Spontaneous \\
\hline $\mathrm{ZnCl}_{2} \cdot 4 \mathrm{MSCZ}$ & $-83197,53$ & $-1,36$ & 83199,16 & $-1,09$ & Exothermic and Spontaneous \\
\hline \multicolumn{6}{|c|}{ Complexes $\mathrm{ZnCl}_{2} .2$ Ligand } \\
\hline $\mathrm{ZnCl}_{2} \cdot 2 \mathrm{SCZ}$ & $-90798,57$ & $-2,17$ & $-90800,47$ & $-1,64$ & Exothermic and Spontaneous \\
\hline $\mathrm{ZnCl}_{2} \cdot 2(\mathrm{E}-\mathrm{EtSCZ})$ & $-92937,06$ & $-2,44$ & $-92939,23$ & $-1,64$ & Exothermic and Spontaneous \\
\hline $\mathrm{ZnCl}_{2} \cdot 2(\mathrm{Z}-\mathrm{EtSCZ})$ & $-92937,33$ & $-2,71$ & $-92939,23$ & $-1,64$ & Exothermic and Spontaneous \\
\hline $\mathrm{ZnCl}_{2} \cdot 2(2 \mathrm{MSCZ})$ & $-92936,24$ & $-2,18$ & $-92938,42$ & $-1,37$ & Exothermic and Spontaneous \\
\hline $\mathrm{ZnCl}_{2} \cdot 2(4 \mathrm{MSCZ})$ & $-92936,24$ & $-2,18$ & $-92938,42$ & $-1,37$ & Exothermic and Spontaneous \\
\hline
\end{tabular}

The negative values of the free enthalpies of coordination show that the coordination of the studied semicarbazones is spontaneous process. The enthalpies are negative, so the process concerning the ligands is exothermic.

From the both conformers of ethanalsemicarbazone one obtains the same chelate; instead the Z-ETSCZ was transformed, during the complexation, into the $\mathrm{E}$ - form to avoid congstion with the $\mathrm{ZnCl}_{2}$ system. The value $-1.62 \mathrm{eV}$ obtained in the column of the enthalpies of coordination for the complex Z-ETSCZ would be the sum of the coordination enthalpy of this complex and the reorganization energy of the Z-ETSCZ molecule to E-ETSCZ one.

It should be noted that the introduction of the methyl group in semicarbazone did not involve any significant modification of the properties.

\section{Conclusion}

The present works constitute a theoretical study of the coordination of the molecules of some semicarbazones. These were semicarbazone, E-ethanalsemicarbazone, Z-ethanalsemicarbazone, 2-methylsemicarbazone,

4-methylsemicarbazone. This has been possible through the analysis of coordination indicators such as bond lengths, atomic charges, electrostatic atom potentials, boundary orbitals, and atomic electrophilic superdelocalizability indexes.

The results from our calculations showed that these molecules are able to form complexes with metal ions. $\mathrm{Zn}^{2+}$ is one of those ions. It has been found that the most favorable coordination site is the oxygen atom for these semicarbazones followed by the trigonal nitrogen atom. The methyl group in semicarbazone did not involve any significant modification of the properties.

The complexes obtained with Zinc (II) provided by the zinc (II) chloride are of the proportion Zn / ligand equal to 1/1 and $1 / 2$. The central element, Zn (II), has a tetrahedral structure in all the complexes obtained. The vertices of the tetrahedra are occupied by two chlorine atoms and two oxygen atoms for the 1/2 structures; in the 1/1 structures, the vertices of the tetrahedron are occupied by the two $\mathrm{Cl}$ atoms, the $\mathrm{O}$ atom and the trigonal $\mathrm{N}$ atom of the ligand. The complexes of the proportion $\mathrm{Zn} /$ ligand equal to $1 / 1$ are chelates resulting from the coordination of the ligands via the $\mathrm{O}$ and Ntrigonal atoms thus forming a five-membered ring.

All complexation processes were spontaneous and exothermic under the study conditions of $25^{\circ} \mathrm{C}$ and one atmosphere. 


\section{References}

Alomar, K. (2012). Synthese, caracterisation st ructurale de complexes de thiosemicarbazones, semicarbazones et oximes mono et bifonctionnelles d'ald_ehydes thiopheniques avec des metaux de transition. Etude de propriétés biologiques. (Doctoral dissertation) https://tel.archives-ouvertes.fr/tel-01277204

Andersen, O. (1999). Principles and recent developments in chelation treatment of metal intoxication, Chem. Rev., 99, 2683-2710. https://doi.org/10.1021/cr980453a

Azizov, M. A. (1969). O Komplexnih soédineniah nekotorih microélémentov s bioactivnimi vechestvami, (ed. Médétsina), Tachkent

Bäuerlein, E., Arias, J. L. et al. (2007). Handbook of biomineralization: biological aspects and structure formation, 1, Biological aspects and structure formation, 309-327. https://doi.org/10.1002/9783527619443

Bäuerlein, E., Kawasaki, K. et al. (2007). Handbook of biomineralization: biological aspects and structure formation, 1, Biological aspects and structure formation.

Bäuerlein, E.; Frankel, R. B. et al., (2007). Handbook of biomineralization: biological aspects and structure formation, 1, Biological aspects and structure formation. https://doi.org/10.1002/9783527619443

Büchel, K. H., Moretto, H. H. et al., (2000). Industrial inorganic chemistry. https://doi.org/10.1002/9783527613328

Caravan, P., Ellison, J. J. et al. (1999). Gadolinium(III) chelates as MRI contrast agents: structure, dynamics, and applications, Chem. Rev., 99, 2293-2352. https://doi.org/10.1021/cr980440x

Douglas, X., \& West, A. (1993). Coordination Chemistry Reviews, 123(s1-2), 49-71.

Frisch, M. J. et al. (2009). Gaussian 09W, Gaussian Inc., Pittsbourgh PA,

Gómez-Jeria, J. S. (2014). D-Cent-QSAR, 1. Santiago, Chile.

Kembal, J. ((1975). Sovrémiénaya obchaya himia, (ed. Mir), Moscou

Kenneth, L. (1999). Macroscale and Microscale Organic Experiments, (3rd ed.), ISBN 978-0-395-90220-2, LCCN 98072094

Knouniats, I. L. (1990). Himitcheskaya Entsiklopédiya, Ed. Sovietskaya entsiklopédiya, Moscou .

Kuevi, U. A. (1992). Etude quanto-chimique de la coordination du benzamide, du N,N-diméthylbenzamide et du succinimide, (Unpublished master's thesis), Université Russe de l'Amitié des Peuples, Moscou, Russia

Mason, R. (1961). Acta crystallogr., 14, 720. https://doi.org/10.1107/S0365110X61002199

Picot, D. (2008). Modelisation de la reaction d'alkylation du motif zinc-thiolate, (Doctoral dissertation). https://pastel.archives-ouvertes.fr/pastel-00004269

Potapov, V., \& Tatarintchik, S. (1988). Chimie organique, (Ed. Mir), Moscou

Sakirigui, A. et al, (2011). J. Soc. Ouest-Afr. Chim., 31, 11-20.

Sakurai, H., Yoshikawa, Y., \& Yasui, H. (2008). Chem Soc Rev., 37(11), 2383-2392. https://doi.org/10.1039/b710347f

Shaw, C. F. (1999). Gold-based therapeutic agents, Chem. Rev., 99, 2589-2600. https://doi.org/10.1021/cr980431o

Williams, D. (1975). Mettalli Jizni, (ed. Mir) Moscou .

Wong, E., \& Giandomenico, C. M. (1992). Current status of platinum-based antitumor drugs, Chem. Rev., 99, 2451-2466. https://doi.org/10.1021/cr980420v

Yatsimirskiï, K. V. (1976). Vvedenie v bioniorganitcheskouyou himiou, (ed. NaoukovaDoumka).

\section{Copyrights}

Copyright for this article is retained by the author(s), with first publication rights granted to the journal.

This is an open-access article distributed under the terms and conditions of the Creative Commons Attribution license (http://creativecommons.org/licenses/by/4.0/). 